\title{
Kegiatan Pengembangan Diri Dalam Menggali Potensi Anak Tunanetra Di Panti Tunanetra Aisyiyah Ponorogo
}

\author{
Heny Kristiana Rahmawati \\ IAIN Kudus \\ henykristiana.rahma@gmail.com
}

\begin{abstract}
Abstrak
Pada setiap orang ada kecenderungan atau dorongan untuk mewujudkan potensinya, dorongan untuk berkembang dan menjadi matang, dorongan untuk mengungkapkan dan mengaktifkan semua kapasitas seseorang. Akibat dari ketunanetraan, maka pengenalan atau pengertian terhadap dunia luar anak, tidak dapat diperoleh secara lengkap dan utuh. Akibatnya perkembangan kognitif anak tunanetra cenderung terhambat dibandingkan dengan anak-anak normal pada umumnya. Apabila lingkungan dapat memberikan kesempatan untuk berbuat, serta membantu anak tunanetra untuk melakukan penyesuaian sosial yang sebaik-baiknya, niscaya perkembangan kepribadian anak tunanetra tidak berbeda sebagaimana layaknya anak normal lainnya. Dalam pembahasanya kajian ini menggunakan pendekatan kualitatif dengan teknik, observasi dan wawancara langsung terhadap kegiatan pengembangan diri anak tunanetra di Panti Asuhan Aisyiyah Ponorogo. Hasil penelitian ini ditemukan bahwa kegiatan pengembangan diri yang dilaksanakan di panti, wajib diikuti oleh seluruh anak asuh. Bentuk kegiatan pengembangan diri yang dilakukan terhadap anak tunanetra di Panti Asuhan Tunanetra Aisyiyah Ponorogo mencangkup 3 jenis kegiatan yaitu Tarbiyah Islamiyah, Pelajaran Kecakapan, dan Ekstra Kurikuler.
\end{abstract}

Kata Kunci: anak tunanetra, pengembangan diri, potensi

Abstract 
On every person there is a tendency or encouragement to realize its potential, the urge to grow and become mature, the compulsion to disclose and enable all of the capacity of a person. As a result of the blind condition, the recognition or understanding of the world outside the child cannot be obtained completely and intact. As a result, the cognitive development of blind children tends to be hampered compared to normal children in general. If the environment can provide an opportunity to act, and help blind children to make the best social adjustments, undoubtedly the development of the blind children personality is not as different as other normal children. In its discussion, this study used a qualitative approach with observation and direct interview techniques for self-development activities of blind children at Aisyiyah Orphanage Ponorogo. The results of this study found that self-development activities carried out in the orphanage must be followed by all foster children. The forms of self-development activities carried out on blind children in the Aisyiyah Orphanage Ponorogo include 3 types of activities, namely Islamic Education, Skills Study, and Extra-Curricular.

Keywords: blind children, self development, potency

\section{A. Pendahuluan}

Manusia berhubungan dengan lingkungan, baik sosial maupun alam melalui kemampuan inderanya. Sekalipun masingmasing indera mempunyai sifat dan karakteristik yang khas, namun dalam bekerjanya memerlukan kerjasama dan keterpaduan diantara indera-indera tersebut sehingga memperoleh pengertian atau makna yang lengkap dan utuh tentang obyek di lingkungannya. Diperlukan kerjasama secara terpadu dan serentak antara indera penglihatan, pendengaran, pengecap, perabaan, dan pembau atau penciuman untuk mendapatkan pengenalan, pengertian, atau makna yang lengkap dan utuh tentang lingkungannya.

Akibat dari ketunanetraan, maka pengenalan atau pengertian terhadap dunia luar anak, tidak dapat diperoleh secara lengkap dan utuh. Akibatnya perkembangan kognitif anak tunanetra cenderung terhambat dibandingkan dengan anak-anak normal pada umumnya. Hal ini disebabkan perkembangan kognitif tidak saja erat kaitannya 


\section{Kegiatan Pengembangan Diri Dalam Menggali Potensi Anak ...}

dengan kecerdasan atau kemampuan intelegensinya, tetapi juga dengan kemampuan indera penglihatannya.

Akses-akses negatif yang ditampakkan oleh anak tunanetra sebenarnya tidak lepas dari sikap lingkungan yang kurang bijaksana terhadap anak tunanetra. Oleh karena itu, jika lingkungan dapat memberikan kesempatan untuk berbuat, serta membantu anak tunanetra untuk melakukan penyesuaian sosial yang sebaik-baiknya, niscaya perkembangan kepribadian anak tunanetra tidak berbeda sebagaimana layaknya anak normal lainnya.

Di sisi lain yang tidak kalah pentingnya dalam penyesuaian sosial anak tunanetra adalah peran pendidik. Peran pendidik selain mengarahkan dan membina pengetahuan anak tunanetra tentang kenyataan yang ada di sekitarnya, juga menumbuhkan kepercayaan diri serta menanamkan perasaan bahwa dirinya dapat diakui dan diterima oleh lingkungannya. Untuk itulah kegiatan pengembangan diri sangat penting untuk diberikan kepada anak tunanetra agar mereka semakin menemukan kebermaknaan dalam masyarakat dan lingkungan.

\section{B. Pembahasan}

\section{Pengembangan Diri}

Pengembangan Diri adalah ilmu yang berhubungan dengan cara mengembangkan potensi diri sendiri. Pengembangan diri ini berhubungan dengan diri sendiri bukan dengan orang lain. Potensi diri maksudnya adalah sesuatu yang kita punyai yang merupakan kekuatan dan belum tergali secara maksimal. Proses pencerahan adalah salah satu istilah yang biasa dipakai untuk menggambarkan sesuatu yang sebelumnya kita tidak mengerti menjadi paham kemudian (Jibrilia Ang, 2012).

Selain itu dijelaskan pula bahwa pengembangan kepribadian islam merupakan usaha sadar yang dilakukan oleh individu untuk memaksimalkan daya-daya insaninya, agar ia mampu realisasi dan aktualisasi diri lebih baik, sehingga memperoleh kualitas hidup di dunia maupun di akhirat (Abdul Mujib, 2006 : 388).

\section{Cara Belajar dan Kecerdasan}


Secara umum cara belajar peserta didik dapat dikategorikan ke dalam empat hal, yaitu cara somatic, auditif, visual, dan intelektual. Cara belajar somatic adalah pada pembelajaran yang lebih menekankan pada aspek gerak tubuh atau belajar dengan melakukan. Cara belajar auditif adalah cara belajar yang lebih menekankan pada aspek pendengaran. Cara belajar visual lebih menekankan pada aspek penglihatan. Cara belajar intelektual lebih menekankan pada aspek penalaran/logika dengan penekanan pada aspek mencari solusi pemecahan(Futiati Romlah, 2006:41). Pada cara belajar ini, tentunya anak tunanetra tidak dapat menggunakan cara belajar secara visual. Untuk itulah kegiatan pengembangan diri ini dimaksudkan agar walaupun anak tunanetra memiliki keterbatasan dalam cara belajar visual, namun melalui cara belajar yang lain potensi dalam diri anak masih dapat dikembangkan dengan baik.

Pada tahun 1983 Howard Gardner dalam bukunya The Theory of Multiple Intelegence, mengusulkan tujuh macam komponen kecerdasan, yang disebutnya dengan Multiple Intelegence (Intelegensi Ganda). Sekarang tujuh kecerdasan tersebut di atas sudah bertambah lagi dengan satu komponen kecerdasan yang lain, yaitu (8) kecerdasan naturalis.

a. Kecerdasan Linguistic-Verbal, Kemampuan untuk menyusun pikirannya dengan jelas juga mampu mengungkapkan pikiran dalam bentuk kata-kata seperti berbicara, menulis, dan membaca.

b. Kecerdasan Logika-Matematik, Kecerdasan ini ditandai dengan kemampuan seseorang untuk berinteraksi dengan angka-angka dan bilangan, berpikir logis dan ilmiah, adanya konsistensi dalam pemikiran.

c. Kecerdasan Spasial-Visual, Kecerdasan ini ditunjukkan oleh kemampuan seseorang untuk melihat secara rinci gambaran visual yang terdapat di sekitarnya.

d. Kecerdasan Ritmik-Musik, Kecerdasan ritmik-musikal adalah kemampuan seseorang untuk menyimpan nada di dalam benaknya, untuk mengingat irama, dan secara emosional terpengaruh oleh musik.

e. Kecerdasan Kinestetik, Kecerdasan ini ditunjukkan oleh kemampuan seseorang untuk membangun hubungan yang 


\section{Kegiatan Pengembangan Diri Dalam Menggali Potensi Anak ...}

penting antara pikiran dengan tubuh, yang memungkin tubuh untuk memanipulasi objek atau menciptakan gerakan.

f. Kecerdasan Interpersonal, Kecerdasan ini berkait dengan kemampuan seseorang untuk berinteraksi dengan orang lain. Pada saat berinteraksi dengan orang lain, seseorang harus dapat memperkirakan perasaan, temperamen, suasana hati, maksud dan keinginan teman interaksinya, kemudian memberikan respon yang layak.

g. Kecerdasan Intrapersonal, Kecerdasan intrapersonal adalah kecerdasan yang menyangkut kemampuan seseorang untuk memahami diri sendiri dan bertanggung jawab atas kehidupannya sendiri.

h. Kecerdasan Naturalis, Kemampuan untuk mengenali dan mengelompokkan serta menggambarkan berbagai macam keistimewaan yang ada di lingkungannya. Beberapa pekerjaan yang membutuhkan kecerdasan naturalis ini adalah ahli biologi atau ahli konservasi lingkungan (Ardi, 2011).

Gardner dalam bukunya Suparlan (2004:39) mengingatkan kepada kita bahwa anak-anak memiliki kemampuan yang berbedabeda sesuai dengan bakat dan minatnya. Gardner juga menegaskan bahwa satu-satunya sumbangan paling penting untuk perkembangan anak adalah membantunya untuk menemukan bidang yang paling cocok dengan bakatnya, yang akan membuatnya puas dan kompeten.

Sedangkan menurut Abdul Mujib dan Jusuf Mudzakir dalam bukunya Nuansa-Nuansa Psikologi Islam (2011:319), jenis-jenis kecerdasan pada diri seseorang sangat beragam seiring dengan kemampuan atau potensi yang ada pada dirinya. Topik ini lebih memfokuskan pada penelaahan kecerdasan qalbiah, yaitu kecerdasan intelektual, kecerdasan emosional, kecerdasan moral, kecerdasan spiritual, dan kecerdasan beragama.

1) Kecerdasan Intelektual, Kecerdasan qalbu yang berkaitan dengan penerimaan dan pembenaran pengatahuan yang bersifat intuitif ilahiah. Seperti wahyu untuk Rasul dan ilham untuk orang shaleh.

2) Kecerdasan Emosional, Kecerdasan qalbu yang berkaitan dengan pengendalian nafsu-nafsu impulsif dan agresif. Kecerdasan ini menyarankan seseorang untuk bertindak secara hati-hati, 
waspada, tenang, sabar, dan tabah ketika mendapat musibah, dan berterimakasih mendapat kenikmatan.

3) Kecerdasan Moral, Kecerdasan qalbu yang berkaitan dengan hubungan dengan sesama manusia dan alam semesta. Kecerdasan ini mengarahkan seseorang untuk bertindak dengan baik sehingga orang lain merasa senang dan gembira kepadanya tanpa ada rasa sakit.

4) Kecerdasan spiritual, Kecerdasan qalbu yang berhubungan dengan kualitas batin seseorang, kecerdasan ini mengarahkan seseorang untuk berbuat lebih manusiawi, sehingga dapat menjangkau nilai-nilai luhur yang mungkin belum tersentuh oleh akal fikiran manusia.

5) Kecerdasan beragama, Kecerdasan qalbu yang berhubungan dengan kualitas beragama dan ber-Tuhan. Kecerdasan ini mengarahkan seseorang untuk berperilaku secara benar yang puncaknya menghasilkan ketaqwaan secara mendalam.

Dalam kegiatan pengembangan diri ini, segala bentuk kegiatan sebagian besar diarahkan kepada kecerdasan beragama. Agar potensi-potensi yang ada dalam diri anak dapat terarahkan sesuai dengan kualitas beragama yang baik. Selain lingkungan agama yang mendukung, kegiatan yang dilakukan pun harus mempunyai tujuan beragama yang maksimal dalam pencapaiannya.

\section{Potensi Anak Tunanetra}

\section{a. Potensi}

Dari segi peristilahan, kata potensi berasal dari bahasa Inggris to potent yang berarti keras atau kuat. Dalam pemahaman lain kurang lebih semakna, kata potensial mengandung arti kekuatan, kemampuan, dan daya, baik yang belum maupun yang sudah terwujud, tetapi belum optimal. Potensi merupakan suatu daya yang dimiliki oleh manusia. Akan tetapi, daya tersebut belum dimanfaatkan secara optimal. Oleh karena itu, yang menjadi tugas berikutnya bagi manusia yang berpotensi adalah bagaimana mendayagunakan potensi tersebut untuk meraih prestasi (Asrul, 2011). 


\section{Kegiatan Pengembangan Diri Dalam Menggali Potensi Anak ...}

\section{b. Anak Tunanetra}

Dalam bidang pendidikan luar biasa, anak dengan gangguan penglihatan lebih akrab disebut anak tunanetra. Pengertian tunanetra tidak saja mereka yang buta, tetapi mencakup juga mereka yang mampu melihat tetapi terbatas sekali dan kurang dapat dimanfaatkan untuk kepentingan hidup sehari-hari terutama belajar. Jadi anak-anak dengan kondisi penglihatan yang termasuk "setengah melihat", "low vision", atau rabun bagian dari kelompok anak tunanetra (Sutjihati Somantri, 2006:65).

Berdasarkan acuan tersebut, anak tunanetra dapat dikelompokkan menjadi dua macam, yaitu : a) Buta; Dikatakan buta jika anak sama sekali tidak mampu menerima rangsang cahaya dari luar, b) Low Vision (Penglihatan Lemah); Bila anak masih mampu menerima rangsang cahaya dari luar, tetapi ketajamannya lebih dari $6 / 21$, atau jika anak hanya mampu membaca headline pada surat kabar (Sutjihati Somantri, 2006:65).

Secara ilmiah ketunanetraan anak dapat disebabkan oleh berbagai faktor apakah itu faktor dalam diri anak (internal) ataupun faktor dari luar anak (eksternal). Hal-hal yang termasuk faktor internal yaitu faktor-faktor yang erat hubungannya dengan keadaan bayi selama masih dalam kandungan. Kemungkinan karena faktor gen (sifat pembawa keturunan), kondisi psikis ibu, kekurangan gizi, keracunan obat, dan sebagainya. Sedangkan hal-hal yang termasuk faktor eksternal diantaranya faktor-faktor yang terjadi pada saat atau sesudah bayi dilahirkan. Misalnya : kecelakaan, terkena penyakit siphilis yang mengenai matanya saat dilahirkan, pengaruh alat bantu medis (tang) saat melahirkan sehingga sistem persyarafannya rusak, kurang gizi atau vitamin, terkena racun, virus trachoma, panas badan yang terlalu tinggi, serta peradangan mata karena penyakit, bakteri, ataupun virus (Sutjihati Somantri, 2006:66).

Anak tunanetra memiliki keterbatasan atau bahkan ketidakmampuan dalam menerima rangsangan atau informasi dari luar dirinya melalui indera penglihatannya. Penerimaan rangsangan hanya dapat dilakukan melalui pemanfaatan indera-indera lain di luar indera penglihatannya. Namun karena dorongan dan kebutuhan anak untuk tetap mengenal dunia sekitarnya, anak tunanetra 
biasanya menggantikannya dengan indera pendengaran sebagai saluran utama penerima informasi (Sutjihati Somantri, 2006:68).

Dalam buku Pengantar Psikopedagogik karya M. Efendi (2008;44) disebutkan bahwa, Heyes seorang ahli pendidikan anak tunanetra telah melakukan penelitian terhadap kondisi kecerdasan anak tunanetra. Kesimpulan hasil penelitiannya sebagai berikut : a. Ketunanetraan tidak secara otomatis mengakibatkan kecerdasan rendah, b. Mulainya ketunanetraan tidak mempengaruhi tingkat kecerdasan, c. Anak tunanetra ternyata banyak yang berhasil mencapai prestasi intelektual yang baik, apabila lingkungan memberikan kesempatan dan motivasi kepada anak tunanetra untuk berkembang, d. Penyandang ketunanetraan tidak menunjukkan kelemahan dalam intelegensi verbal. Hak anak tunanetra dalam memperoleh pengajaran, telah dijelaskan dalam Undang-Undang RI No 20/2003 pasal 5 ayat 2 (2008) bahwa "Warga Negara yang memiliki kelainan fisik, emosional, mental, intelektual, dan/atau sosial berhak memperoleh pendidikan khusus".

Hasil penelitian di atas, setidaknya menegaskan bahwa pada dasarnya kondisi kecerdasan aznak tunanetra tidak jauh berbeda dengan anak normal pada umumnya. Dan untuk mencapai kecerdasan yang sempurna tentunya anak tunanetra perlu dibantu dalam mengembangkan potensi dirinya (fisik, intelektual, emosi, social, dan moral-spiritual) secara optimal melalui berbagai aktivitas yang positif dan konstruktif (membangun).

Pada setiap orang ada kecenderungan atau dorongan untuk mewujudkan potensinya, untuk mewujudkan dirinya, dorongan untuk berkembang dan menjadi matang, dorongan untuk mengungkapkan dan mengaktifkan semua kapasitas seseorang. Dorongan ini merupakan motivasi primer untuk kreativitas ketika individu membentuk hubungan-hubungan baru dengan lingkungannya dalam upaya menjadi dirinya sepenuhnya. Dorongan ini ada pada setiap orang dan bersifat internal, namun membutuhkan kondisi yang tepat untuk diekspresikan (Utami Munandar, 2002:57).

Ketika upaya menggali potensi telah dilakukan, maka penilaian autentik perlu dilakukan terhadap keseluruhan kompetensi yang telah dipelajari siswa melalui kegiatan pembelajaran. Untuk itu, ranah yang perlu dinilai adalah ranah kognitif, afektif, dan 


\section{Kegiatan Pengembangan Diri Dalam Menggali Potensi Anak ...}

psikomotorik (Chatib Munif, 2009:167). Perkembangan Kognitif mengarahkan anak dari yang tidak tahu menjadi tahu, misalnya kemampuan menghafal makhroj, tajwid dan irama pada kegiatan tilawatil Qur'an

Perkembangan Afektif mengarahkan anak dari yang tidak biasa menjadi biasa, misalnya : a) Kedisiplinannya dalam mengikuti kegiatan pengembangan diri secara rutin, b) Motivasinya yang tinggi untuk mengembangkan potensi yang ada dalam dirinya. Perkembangan Perilaku (psikomotorik) mengarahkan anak dari yang tidak bisa menjadi bisa, misalnya : a) Anak mampu memainkan alat musik dengan lebih mahir, b) Anak menunjukkan prestasi bermain musik dengan sangat baik.

\section{Kegiatan Pengembangan Diri Di Panti Tunanetra Aisyiyah Ponorogo}

Kegiatan pengembangan diri yang dilaksanakan di panti, wajib diikuti oleh seluruh anak asuh yang berada di panti. Tentu saja hal ini dimaksudkan agar mereka dapat memperoleh pendidikan yang sangat cukup tidak hanya di lingkungan tempat mereka bersekolah (SLB) tetapi juga di tempat lingkungan mereka tinggal, yaitu di panti. Dasar dari kegiatan pengembangan diri ini adalah :

a. Al Quran Surat 'Abasa ayat 1-4

1). Dia (Muhammad) bermuka masam dan berpaling,

2). karena telah datang seorang buta kepadanya

3). tahukah kamu barangkali ia ingin membersihkan dirinya (dari dosa),

4). atau Dia (ingin) mendapatkan pengajaran, lalu pengajaran itu memberi manfaat kepadanya

Orang buta itu bernama Abdullah bin Ummi Maktum. Dia datang kepada Rasulullah s.a.w. meminta ajaran-ajaran tentang Islam; lalu Rasulullah s.a.w. bermuka masam dan berpaling daripadanya, karena beliau sedang menghadapi pembesar Quraisy dengan pengharapan agar pembesar-pembesar tersebut mau masuk Islam. Maka turunlah surat ini sebagai teguran kepada Rasulullah s.a.w. 
b. Al Qur'an Surat Ali Imron ayat 104

104. dan hendaklah ada di antara kamu segolongan umat yang menyeru kepada kebajikan, menyuruh kepada yang ma'ruf dan mencegah dari yang munkar, merekalah orang-orang yang beruntung.

Kedua ayat tersebutlah yang menjadi dasar Panti Asuhan Tunanetra Aisyiyah Ponorogo mengadakan sebuah kegiatan pengembangan diri untuk menggali potensi-potensi yang ada pada diri anak tunanetra. Kegiatan pengembangan diri dilaksanakan setiap hari sesuai dengan jadwal yang berlaku. Seperti yang disampaikan oleh Sari Saputri selaku Pengurus Panti Urusan Pendidikan bahwa pengembangan diri baik dari sisi keilmuan agama, umum, dan kreatifitas dilaksanakan ada yang secara harian dan juga mingguan. Untuk harian lebih ditekankan pada pembelajaran diniyah dengan materi ilmu keagamaan, sedangkan untuk kreatifitas dilaksanakan secara seminggu sekali yang biasanya disebut dengan kegiatan ekstra kurikuler.

Untuk menguatkan pernyataan tersebut, dari hasil dokumentasi dapat kita lihat bahwa pihak panti sudah menyediakan wadah pengembangan diri yang memadai dan sesuai dengan potensi yang ada pada masing-masing anak. Di Panti Tunanetra Aisyiyah Ponorogo terdapat banyak sekali kegiatan yang dapat menunjang potensi diri pada anak baik dari sisi keilmuan keislamannya maupun keahlian berkreasi. Kegiatan pengembangan diri ini tercakup dalam 3 jenis kegiatan yang dilakukan baik secara harian maupun mingguan. Kegiatannya sebagai berikut : pertama, Tarbiyah Islamiyah: kegiatan ini mencangkup keilmuan keislaman yang diantaranya adalah pembelajaran aqidah, akhla, fiqih, tafsir Al-Qur'an, bahasa arab, sejarah kebudayaan islam dan ilmu kemuhammadiyahan. Kedua, Pelajaran Kecakapan: jenis pengembangan diri ini mengarah pada keilmuan secara umum yaitu bahasa inggris, matematika dan untuk anak asuh putri terdapat 1 pembelajaran yang menarik yaitu keputrian. Pengembangan diri bernama keputrian ini mengajarkan apapun yang berkaitan dengan anak putri, misalnya dari sisi ketrampilan diajarkan merangkai bunga, memasak, dari sisi keilmuan terdapat pembelajaran fiqih wanita, motivasi, dan juga halhal lain yang berkaitan dengan anak putri. Dan Ketiga, Ekstra 


\section{Kegiatan Pengembangan Diri Dalam Menggali Potensi Anak ...}

kurikuler : kegiatan ini merupakan kegiatan di luar pembelajaran formal namun wajib diikuti oleh semua anak asuh. Kegiatan yang dilakukan 1 minggu sekali ini banyak mendapat antusias yang sangat baik dari masyarakat, dikarenakan kemampuan mereka yang luar biasa. Kegiatan pengembangan diri ekstra kurikuler ini meliputi tilawah Al-Qur'an, muhadharah, muhadatsah, massage yang telah membuka klinik bersinergi dengan SLB, musik yang seringkali diminta untuk tampil diacara-acara umum, tapak suci putra Muhammadiyah dan kegiatan speaking.

Seluruh kegiatan pengembangan diri yang ada di panti dibina langsung oleh para pengurus panti. Sehingga kebanyakan dari tenaga pengajar yang ada mereka adalah orang-orang yang memiliki latar belakang yang tidak jauh berbeda ataupun sudah lama berada di panti. Meski selain itu juga ada orang yang berada dari luar panti turut menjadi tenaga pengajar disini. Hal ini disampaikan oleh Bapak Hadianto S.Pd.I selaku Wakil Kepala Panti bahwa untuk sementara ini tenaga pengajar yang ada di panti masih sangat terbatas. Sejauh ini tenaga pengajar yang ada kebanyakan adalah pengurus panti tunanetra sendiri. Meski selain itu juga ada tenaga pengajar dari luar panti yang bersedia membantu mengajar dan mengembangkan ilmunya di panti. Namun tetap saja pihak panti masih membutuhkan tenaga pengajar yang sesuai dengan bidangnya agar kegiatan pengembangan diri menjadi semakin maksimal.

Pihak panti masih sangat membutuhkan tambahan tenaga pengajar, namun hal itu bukan berarti menjadi alasan terhambatnya suatu kegiatan. Tetapi alangkah baiknya jika para orang berpendidikan bersedia untuk mengajarkan ilmunya disini tidak hanya sibuk mengejar gelar dan kedudukan saja di pemerintahan. Seringkali terdengar banyak sarjana dan orang berpendidikan yang menganggur dan bingung tidak ada lowongan kerja. Padahal jika kita mau sedikit saja melihat, banyak juga yayasan yang membutuhkan tenaga pengajar dari orang-orang yang memang memiliki kemampuan dan keahlian yang pantas.

Keterbatasan bukan menjadi halangan untuk dapat bersaing di masyarakat. Justru banyak fakta yang membuktikan bahwa justru di balik keterbatasan yang mereka miliki, semangat yang ada dalam diri sangatlah besar. Tentu saja ini semua diawali dengan dukungan 
dari orang-orang terdekat mereka. Untuk melihat sejauh mana hasil dari kegiatan pengembangan diri, pihak panti sangat mendukung anak asuhnya mengikuti perlombaan yang diadakan di masyarakat. Dari dokumentasi yang ada, terdapat beberapa hasil dari anak asuh yang tidak hanya telah berani bersaing dengan orang normal lainnya, namun mereka mampu menunjukkan prestasi yang luar biasa.

Berbagai bentuk prestasi di Luar Panti yang telah diraih diantaranya Juara 3 Lomba Qiro'ah antar panti se-Ponorogo tahun 2011, Juara umum Lomba MTQ (Musabaqah Tilawatil Qur'an) antar panti (piala bergilir) se-Ponorogo tahun 2011, Turut serta dalam Jambore Nasional se-Indonesia tahun 2009, Juara 3 Lomba Cerdas Cermat antar panti se-Ponorogo tahun 2011, Juara 2 Lomba Tartil seKabupaten Ponorogo tahun 2011, Juara 1 Lomba Tilawatil Qur'an seKabupaten Ponorogo tahun 2012, Juara 3 Lomba Qiro'ah seKabupaten Ponorogo tahun 2011, Juara 1 Lomba Qiro'ah MTs seKaresidenan Madiun tahun 2009, Juara 3 Lomba Qiro'ah MA seKaresidenan Madiun tahun 2009, Juara 1 Lomba Wudhu dan Sholat se-Kabupaten Ponorogo tahun 2011, Juara 2 Pildacil se-Karesidenan Madiun tahun 2009, Juara 1 Tembang Mocopat se-Karesidenan Madiun tahun 2010

Sedangkan Prestasi yang pernah diraih oleh siswa tunanetra di Dalam Panti mencakup diantaranya Dalam bidang kemandirian diri (mandi, memasak, menyeterika baju, bersih-bersih lingkungan, makan, minum, beribadah), Lomba kebersihan kamar, Mampu disiplin dalam mengikuti jadwal panti, dan Bertambahnya sisi keilmuan baik ilmu agama maupun ilmu umum.

Selain dari data prestasi yang ada di dalam maupun di luar panti, peneliti melakukan tes uji kompetensi untuk kecerdasan psikomotorik anak. Hal ini dilakukan untuk melihat kemampuan anak yang sesungguhnya dalam menerima materi kegiatan pengembangan diri. Di dalam tes uji kompetensi ini ada 4 kriteria yang dijadikan tolok ukur penilaian. Dikatakan sangat baik jika nilai anak antara 85-100. Baik jika nilai antara 70-84, kategori sedang jika nilai anak antara 55-69, dan dikatakan kurang jika nilai di bawah 50. Hasilnya adalah sebagai berikut :

Berbagai Kegiatan Tarbiyah Islamiyah di Panti Asuhan Tunanetra Aisyiyah Ponorogo diantaranya; a) Mempraktekkan 


\section{Kegiatan Pengembangan Diri Dalam Menggali Potensi Anak ...}

gerakan sholat wajib dan sholat jenazah (hasilnya baik), b) Menafsirkan ayat Al-Qur'an Surat 'Abasa ayat 1-4 (hasilnya baik), c) Menjelaskan sejarah awal mulanya islam masuk ke Indonesia (hasilnya baik). Sedangkan bentuk Kegiatan Pelajaran Kecakapan yang telah dilaksanakan oleh anak-anak panti seperti kegiatan Mengerjakan soal matematika dasar sesuai tingkatan kelasnya masing-masing (hasilnya sedang) dan Khusus untuk anak putri : praktek membuat salah satu jenis keterampilan tangan yang mereka kuasai (hasilnya baik)

Adapun mengenai bentuk Kegiatan Ekstra Kurikuler yang telah berjalan di Panti Asuhan Tunanetra Aisyiyah Ponorogo mencakup a) Praktek muhadharah (hasilnya sangat baik), b) Memainkan alat musik gitar (hasilnya baik) dan, c) Percakapan bahasa inggris (hasilnya sedang) (transkip dokumentasi 09/D/5IV/2013).

Untuk memperkuat data yang ada, maka diadakan pula tes menjawab berbagai macam pertanyaan berkaitan dengan kegiatan pengembangan diri di panti. Pertanyaan yang berbentuk angket ini dilakukan untuk mengetahui sejauh mana mereka menyukai kegiatan pengembangan diri yang dilaksanakan oleh pihak panti. Pertanyaan yang diberikan mengenai pendapat mereka tentang kegiatan pengembangan diri yang kemudian disertai jawaban berupa sangat senang, senang, segan dan tidak senang, yang kemudian keseluruhan hasilnya bisa dilihat pada tabel berikut:

Tabel 1. Aspek Kegiatan Pengembangan Diri dan Hasil pernyataan Siswa

\begin{tabular}{c} 
Aspek \\
\hline Tarbiyah Islamiyah
\end{tabular}$\quad$\begin{tabular}{l} 
1. Aqidah (30 anak menyatakan \\
senang, 28 anak sangat senang) \\
2. Akhlak (42 anak sangat senang, \\
16 anak senang) \\
3. Fiqih (47 anak sangat senang, 11 \\
anak senang) \\
4. Tafsir Al-Qur'an (18 anak sangat \\
senang, 40 anak senang) \\
5. Bahasa arab (21 anak sangat \\
\hline
\end{tabular}


senang, 37 anak senang)

6. SKI (33 anak sangat senang, 25 anak senang)

7. Ilmu Kemuhammadiyahan ( 34 anak sangat senang, 24 anak senang)

Pelajaran Kecakapan

Ekstra Kurikuler
1. Bahasa inggris (13 anak sangat senang, 34 anak senang, 11 anak segan)

2. Matematika (16 anak sangat senang, 37 anak senang, 5 anak segan)

3. Keputrian (42 anak sangat senang, 16 anak senang)

1. Tilawah Al-Qur'an (36 anak sangat senang, 22 anak senang)

2. Muhadharah (47 anak sangat senang, 11 anak senang)

3. Muhadatsah (18 anak sangat senang, 32 anak senang, 5 anak segan, 3 anak tidak senang)

4. Massage (33 anak sangat senang, 25 anak senang)

5. Musik (44 anak sangat senang, 14 anak senang)

6. Tapak suci putra Muhammadiyah (19 anak sangat senang, 39 anak senang)

7. Speaking (11 anak sangat senang, 36 anak senang, 9 anak segan, 2 anak tidak senang).

Dari pendapat dan dokumentasi yang ada dapat diketahui bahwa anak berkebutuhan khusus tunanetra juga memiliki hak yang sama dengan anak normal lainnya dalam belajar dan mengembangkan potensi dirinya. Panti Asuhan Tunanetra Aisyiyah 


\section{Kegiatan Pengembangan Diri Dalam Menggali Potensi Anak ...}

Ponorogo telah mampu menyediakan kegiatan pengembangan diri yang layak. Selain itu juga keberhasilan panti dalam mengembangkan potensi diri dalam anak bisa dilihat dari hasil-hasil prestasi yang telah diraih oleh anak tunanetra. Kegiatan panti menjadi hal yang menarik bagi anak asuh. Mereka merasa kegiatan ini adalah kesempatan yang tidak boleh disia-siakan, karena di sinilah mereka dapat mengembangkan potensi diri dengan maksimal. Seperti yang disampaikan oleh Ummi selaku anak asuh bahwa dengan diadakannya kegiatan pengembangan diri ini beliau bisa menggali kemampuan yang ada dan sesuai dengan diri saya. Selain itu juga lewat kegiatan pengembangan diri ini banyak sekali pengalaman dan hal-hal baru yang bisa dipelajari. Sayang sekali jika kegiatan-kegiatan yang berguna semacam ini tidak dimanfaatkan dengan maksimal.

Begitu baiknya anak asuh panti dalam melaksanakan program pembelajaran. Sedangkan di luar sana masih ada juga yang disekolahkan jauh-jauh bahkan sampai ke jenjang pendidikan yang tinggi namun belum bisa memaknai tanggung jawab yang sesungguhnya dari menuntut ilmu dan mengembangkan kemampuan diri. Pada saat yang sama tentu saja ini menjadikan nilai plus bahwa kesempurnaan fisik bukan menjadi halangan untuk berprestasi. Hal ini diperkuat oleh pernyataan Nabil Ali Azumi yang pernah meraih juara dalam lomba tembang mocopat tingkat kabupaten ketika kelas 5 SD, tepatnya diakhir tahun 2010, Nabil mengatakan bahwa dia ingin membuat orang tuanya bangga. Orang tuanya mengirim dari Bojonegoro kesini dengan harapan supaya bisa memperoleh ilmu dengan baik. Untuk itulah Nabil tidak akan melewatkan kegiatankegiatan yang menurut Nabil positif dan mampu menunjang kemampuannya untuk bisa mandiri di masyarakat kelak.

Meski banyak sekali kegiatan yang harus mereka ikuti. Hal itu tidak menjadikan mereka malas atau bahkan merasa kegiatan yang dilakukannya tidak berguna. Justru dibalik kekurang sempurnaan fisik mereka menjadikan mereka sempurna bersama motivasinya untuk selalu menjadi lebih baik. Selama kesempatan masih ada, selama itu pula manusia berhak membenahi diri menjadi manusia sebagaimana mestinya supaya dia biasa diterima dimana saja. Karena justru mereka akan merasakan kesuksesan dengan melakukan apa saja yang mereka sukai dan disukai oleh banyak 
orang. Pendapat akan semangat tinggi mereka dalam menggali potensi diri semakin diperkuat oleh Sumiati salah seorang anak asuh yang pernah menjadi juara 1 lomba Qiro'ah se-karesidenan Madiun pada tahun 2009. Sumiati merasa bahwa di panti ini dia bisa belajar banyak hal. Hingga pada akhirnya dia bisa menemukan potensi yang benar-benar ada dalam dirinya. Sumiati merasa menjadi orang yang sangat beruntung telah diberikan kesempatan dalam menggali potensi diri, hingga akhirnya mencapai suatu kemenangan dan dapat membanggakan kedua orang tuanya.

Semangat yang tinggi disertai dengan upaya rasional yang terprogram secara sistematis akhirnya melahirkan sebuah kebanggaan. Dengan melihat kegiatan pengembangan diri, motivasi anak asuh yang begitu besar dan potensi-potensi yang ada pada diri mereka, masyarakat akan lebih memahami bahwa terkadang suatu kelebihan yang ada dalam diri tidak dapat tersalurkan jika kita tidak berusaha untuk mencari dan menemukannya sendiri.

\section{Simpulan}

Di Panti Tunanetra Aisyiyah Ponorogo terdapat banyak sekali kegiatan yang dapat menunjang pengembangan potensi diri pada anak baik dari sisi keilmuan keislamannya maupun keahlian kreatifitasnya. Kegiatan pengembangan diri ini tercakup dalam 3 jenis kegiatan yang dilakukan baik secara harian maupun mingguan. Kegiatannya sebagai berikut :

Pada aspek kegiatan Tarbiyah Islamiyah, kegiatan ini mencangkup keilmuan keislaman yang di dalamnya diarahkan kepada pribadi yang berkualitas dalam segi beragamanya serta mengarahkan seseorang berperilaku secara benar yang puncaknya menghasilkan ketaqwaan yang mendalam. Diantaranya adalah pembelajaran aqidah guna memperkuat kecerdasan qalbu pada anak, pembelajaran akhlak yang merupakan perwujudan perilaku dari qalbu, fiqih agar anak mengetahui secara benar hukum-hukum yang mendasari orang islam berperilaku, tafsir Al-Qur'an untuk lebih mendalami makna ayat-ayat yang terkandung di dalamnya, bahasa arab, sejarah kebudayaan islam dan ilmu kemuhammadiyahan.

Sedangkan pada aspek kecakapan, Jenis pengembangan diri ini mengarah pada keilmuan secara umum. Sehingga dalam hal ini 


\section{Kegiatan Pengembangan Diri Dalam Menggali Potensi Anak ...}

anak diarahkan agar kelak siap bersaing dikehidupan masyarakat. Bentuk kegiatan pembelajaran yaitu: bahasa inggris, matematika dan khusus untuk anak putri terdapat satu kegiatan bernama keputrian. Dalam kegiatan keputrian ini anak mempersiapkan diri untuk lebih siap dan mandiri dalam sehari-hari. Misalnya, menjahit, memasak, membuat kue, membuat bros, selain itu juga terdapat pembelajaran yang lebih mendalam tentang pribadi anak putri seperti emansipasi, motivasi diri, haid, fiqih wanita dan hal-hal lain yang berkaitan dengan anak putri.

Pada aspek ekstra kurikuler, Kegiatan yang dilaksanakan dalam seminggu sekali ini merupakan bentuk pengembangan diri yang lebih diarahkan pada kemampuan psikomotorik anak. Kegiatan ini juga wajib diikuti oleh seluruh anak asuh, namun mereka bebas memilih satu atau beberapa yang sesuai dengan bakat serta minat mereka. Kegiatan pengembangan diri ekstra kurikuler ini meliputi tilawah Al-Qur'an, muhadharah agar anak memiliki sikap berani dan percaya diri berbicara di depan umum, muhadatsah, massage yang telah membuka klinik bersinergi dengan SLB, musik yang telah diakui kualitasnya hingga sering diundang di acara hajatan masyarakat sekitar, tapak suci putra Muhammadiyah dan kegiatan speaking untuk memperdalam ilmu berbahasa.

Di Panti Asuhan Tunanetra Aisyiyah berupaya dalam memenuhi kebutuhan pengembangan diri yang sesuai dengan potensi masing-masing anak. Sehingga untuk menilai apakah kebutuhan tersebut sudah terpenuhi atau belum, bentuk kegiatan pengembangan diri akan diklasifikasikan ke dalam 8 tingkat kecerdasan. Sehingga akan lebih terlihat kesesuaian potensi dengan kegiatan pengembangan diri yang diikuti.

Kecerdasan Linguistik Verbal adalah Kecerdasan dalam bentuk kata-kata seperti berbicara, menulis, dan membaca, yaitu : Bahasa Arab, Bahasa Inggris, Tilawah Qur'an, Muhadharah, Speaking, Tafsir Al-Qur'an, Logika Matematik. Kecerdasan dalam berinteraksi dengan angka-angka dan bilangan, berfikir logis dan ilmiah, adanya konsistensi dalam pemikiran, yaitu Matematika Spasial Visual maksudnya adalah Kecerdasan dalam melihat rinci gambaran visual yang terdapat di sekitarnya, yaitu Sejarah Kebudayaan Islam Ritmik 
Musik berarti Kecerdasan dalam menyimpan nada di dalam benaknya, mengingat irama, yaitu Musik

Kinestetik adalah Kecerdasan yang memungkinkan tubuh untuk memanipulasi objek atau menciptakan gerakan, yaitu : Tapak suci putra Muhammadiyah, Keputrian, Massage Interpersonal ialah Kecerdasan yang berkaitan dengan kemampuan seseorang untuk berinteraksi dengan orang lain, yaitu : Akhlak, Muhadatsah, Intrapersonal. Kecerdasan seseorang untuk memahami diri sendiri dan bertanggung jawab atas kehidupannya sendiri, yaitu : Aqidah, Fiqih, Naturalis. Kecerdasan dalam mengelompokkan serta menggambarkan berbagai macam keistimewaan yang ada di lingkungannya, yaitu: Ilmu Kemuhammadiyahan.

Bentuk kegiatan pengembangan diri yang sesuai dengan penilaian perkembangan ke dalam 3 aspek kognitif, afektif dan psikomotorik. Kegiatan tersebut yaitu : Perkembangan kognitif mengarahkan anak dari yang tidak tahu menjadi tahu, yaitu :Aqidah, Fiqih, Sejarah Kebudayaan Islam, Ilmu Kemuhammadiyahan, Matematika

Perkembangan afektif mengarahkan anak dari yang tidak biasa menjadi biasa, yaitu : Speaking, Tafsir Al-Qur'an, Muhadharah, Akhlak, Muhadatsah, Sholat, Puasa, Berdoa. Perkembangan Psikomotorik mengarahkan anak dari yang tidak bisa menjadi bisa, yaitu : Musik, Massage, Tapak Suci Putra Muhammadiyah, Bahasa Arab, Bahasa Inggris, Keputrian, Tilawah Qur'an, Sholat, Puasa, Berdoa 


\section{Kegiatan Pengembangan Diri Dalam Menggali Potensi Anak ...}

\section{DAFTAR PUSTAKA}

Al-Quran Terjemah,

Abdul Mujib, Jusuf Mudzakir, Nuansa-Nuansa Psikologi Islam, Jakarta:PT Raja Grafindo Persada,2011.

Abdul Mujib, Kepribadian Dalam Psikologi Islam, Jakarta : PT Raja Grafindo Persada, 2006.

Agoes Soejanto, Psikologi Perkembangan, Jakarta: PT Rineka Cipta, 2005.

Ardi, Jenis-Jenis Intelegensi Menurut Dr. Howard Gardner, (online), http://www.psy chologymania.com/2011/07/jenis-jenisintelegensi-menurut-howard.html.

Asrul, Pengertian Potensi, (online), http://id.scribd.com/doc/92844558/Pengertian-Potensi.

Chatib Munif, Sekolahnya Manusia, Bandung: PT Mizan Pustaka, 2009.

Futiati Romlah, Psikologi Belajar Pendidikan Agama Islam, (Ponorogo: STAIN Ponorogo PRESS, 2006.

Jibrilia Ang, Pengertian Pengembangan Diri, (online), http:// www. siswo.web.id /2012 /08/pengertian- pengembangan- diri. html.

Mohammad Efendi, Pengantar Psikopedagogik anak berkelainan, Jakarta: PT Bumi Aksara, 2008.

Solihin Mukhtar, et al., Hakikat Manusia, Bandung: CV Pustaka Setia, 2005.

Suparlan, Mencerdaskan Kehidupan Bangsa (Yogyakarta: Hikayat Publishing, 2004), 39.

Sutjihati Somantri, Psikologi Anak Luar Biasa, Bandung: PT Refika Aditama, 2006.

Undang-undang Republik Indonesia tentang Sistem Pendidikan Nasional No 20 Tahun 2003, Bandung: Citra Umbara, 2003.

Utami Munandar, Kreatifitas dan Keberbakatan, Jakarta: PT Gramedia Pustaka, 2002.

Yusuf Syamsu, Teori Kepribadian, Bandung: PT. Remaja Rosdakarya, 2008. 